\title{
A RISING CONCERN: A CASE OF PERFORATION OF THE FLOOR OF THE MOUTH CAUSED BY TONGUE PIERCING
}

\author{
Deniz Ladin Özdemir ${ }^{1}$, Kemal Kef ${ }^{2}$
}

${ }^{1}$ Istanbul Okan University Faculty of Medicine, Istanbul, TURKEY

${ }^{2}$ Department of Otolaryngology, Private Kesan Hospital, Edirne, TURKEY

\section{ABSTRACT}

Aims: The aim of this study is to present a case of an infection in the oral cavity due to tongue piercing perforated into the floor of the mouth, thus to raise concern over the increasing popularity of tongue piercing in spite of its risks including perforation in the oral cavity and oral ulcers.

Case Report: A sixteen-year-old female patient presented to the clinic with lesions and extreme pain in her oral cavity. The thorough examination showed displacement of the piercing through the tongue, causing a perforation of the floor of the mouth. The piercing was surgically removed. The ulcers were treated with medication. The patient was advised to get professional help and was instructed to pay close attention to oral hygiene in case of reiterated demand for tongue piercing.

Conclusion: It is important to ensure that piercing is inserted by a specialist under sterile conditions to prevent complications. If a surgical operation is needed to treat the complications occurred, the clinicians must be aware of the critical veins and nerves that are located in the oral cavity and they should be very careful not to cause any harm during the operation.

Keywords: Tongue, inflammation, ulcer

\section{INTRODUCTION}

Piercing is a type of jewelry that is permanently inserted into the body. Lately, tongue piercings are gaining increasing popularity and mostly preferred by young people (1). Piercings may cause problems such as pain, inflammatory reactions, edema and dental problems if inserted in unsanitary conditions by unqualified people $(2,3)$.

A biofilm is a thick mucoid matter that contains and promotes the development of the bacteria around itself (4). Even in case of appropriate oral hygiene habits, a piercing inside the mouth is often covered with biofilm containing various bacteria such as normal flora, opportunistic and/or inflammatory. The biofilm that covers the piercing acts as a reservoir for bacteria and causes complications by infecting the piercing channel, which is located inside the oral soft tissues (2, $3,5)$. This report presents a case of an infection in the oral cavity caused by tongue piercing, which was embedded in the tongue and also led to a rare case of perforation of the floor of the mouth.

\section{CASE REPORT}

A sixteen-year-old female patient presented to the Department of Otolaryngology in Private Keşan Hospital with severe pain and lesion on the underside of her tongue and at the base of her mouth. A barbell-shaped tongue piercing with a bead on each end was inserted two months ago on her median lingual sulcus. The patient's medical history was insignificant and she was not taking any medications. During the physical examination, it was noted that the upper bead of the barbell-shaped piercing, which was supposed to be seen on top of the tongue, was not visible. It was embedded in between the muscles of the tongue but was not fully covered by mucosa. At the bottom of the tongue, piercing with the bead was still screwed on. It was visible under the tongue and it perforated the floor of the mouth. The incision being $12 \mathrm{~mm}$ in width and 16 $\mathrm{mm}$ in length, caused infections and ulcers in both undersides of the tongue and floor of the mouth. (Figure 1). Since all information was collected from the patient, no further investigations were needed. The patient was taken to the operating room and lidocaine spray was 
applied for local anesthesia. In the operation, the bottom bead of the tongue piercing was carefully screwed off and rest of it was drawn completely out from the surface of the tongue while avoiding any contact that may harm the veins, nerves and muscles located nearby (Figure 2-3). For post-op treatment, the patient was given chlorhexidine oral rinse and tablets containing paracetamol and propyphenazone. A week later, in the follow-up appointment, the lesions on the floor of the mouth and underside of the tongue were found to be healed and the patient had no complaints. To prevent the recurrence of this condition, the patient was informed about the importance of having the piercing inserted by a specialist under sterile conditions.

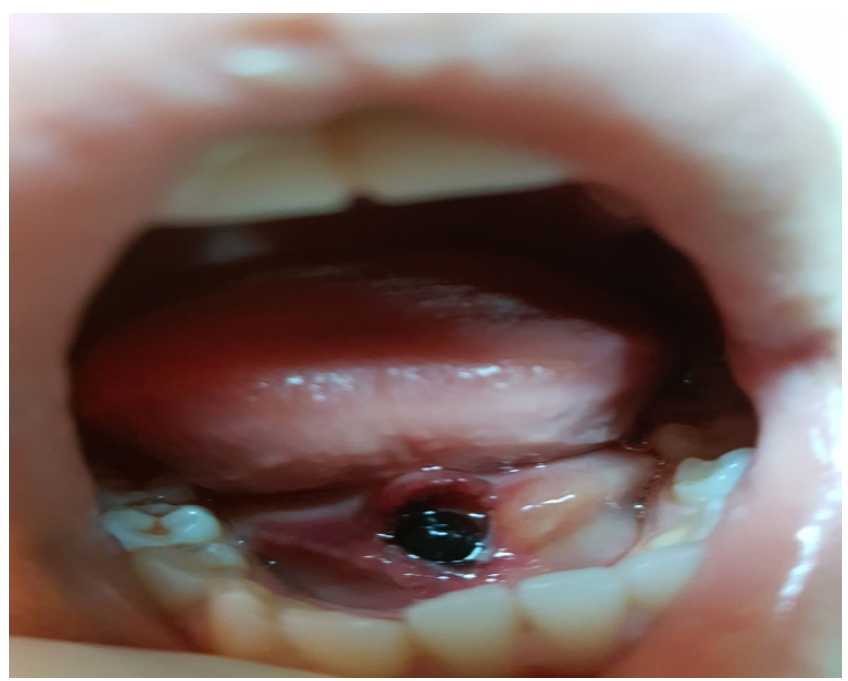

Figure 1: The perforation of the floor of the mouth caused by the barrel-shaped tongue piercing.

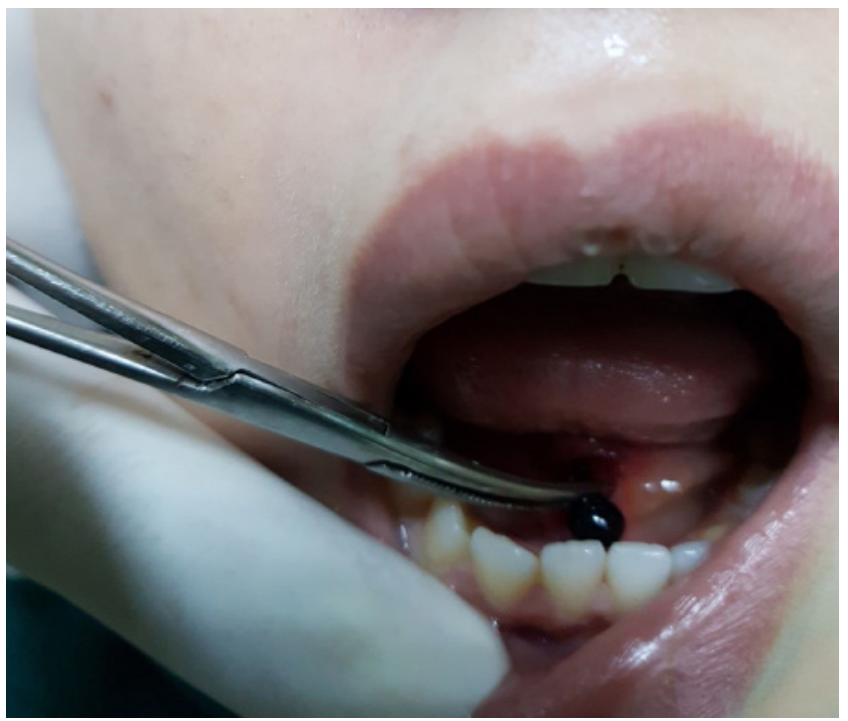

Figure 2: The removal of the barbell shaped tongue piercing.

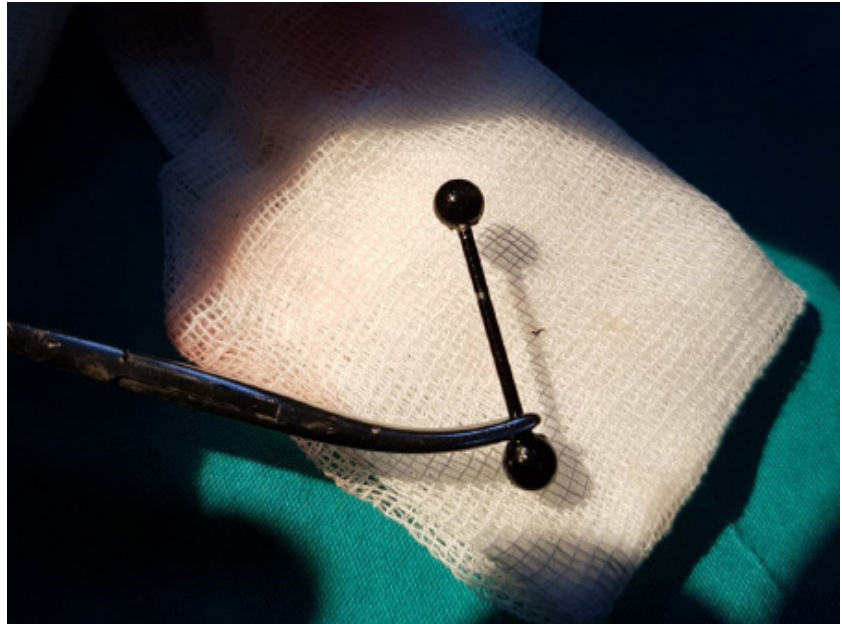

Figure 3: The removed barbell shaped tongue piercing.

\section{DISCUSSION}

The popularity of tongue piercing is growing day by day along with its complications (6). The case control study by Ziebolz et al. (7) showed that the most popular type of tongue piercing among the young people between the ages of sixteen and twenty-four was the barbell-shaped piercing.

A tongue piercing is embedded in the soft tissue of the tongue and runs through its muscles vertically (8). A tongue piercing's location, angle and firmness determine the risk of infection. A tight tongue piercing could cause necrosis due to pressure and may lead to surgical operations as shown in this very case (9).

In a case series by López-Jornet et al. (4) conducted on 70 patients who had oral and facial piercings, $60 \%$ of the subjects reported pain and $34.3 \%$ had inflammatory reactions associated with piercing.

Oral hygiene is a significant determinant of inflammation. Bacteria that are contained in the oral cavity contaminate the piercing tract and cause inflammation. More bacteria proliferate as the oral hygiene diminishes (10).

As shown in all three cases in the study of Shacham et al. (9) tongue piercing can cause swelling of both the tongue and the floor of the mouth. The case report of Bryan et al. (11) has shown that edema causes the barbell to slip and be relocated in between the tongue muscles that are later on covered over with mucosa creating ulcers in oral cavity. This case was also supported 
by the reports of Dayakar et al. (6), Farah et al. (12), Shinohara et al. (13) and Escuardo-Castaño et al. (14).

With the treatment, the healing process begins immediately and the piercing tract proceeds to close within an hour (15).

Complications can be preventable by informing young people about sterilization conditions and recommending consultation to specialists $(7,12)$.

In conclusion, it is important to ensure that piercing is inserted by a specialist under sterile conditions. Oral hygiene is essential to prevent any risk of bacterial colonization that might cause infection in the oral cavity, mostly around the perforation line caused by the piercing. To prevent further harm, tongue piercing should be fixed in the tongue firm enough not to let it move around yet loose enough to avoid any necrosis due to its tightness. If a surgical operation is needed, the clinicians must be aware of the critical veins and nerves that are located in the oral cavity and they should be very careful not to cause any harm during the operation.

\section{Ethics Committee Approval: N/A}

Informed Consent: Written informed consent was obtained from the participants of this study.

Conflict of Interest: The authors declared no conflict of interest.

Author contributions: Concept: FÖ, YCÖ, KE. Design: FÖ, YCÖ, KE. Supervision: FÖ. Resources: FÖ, YCÖ, KE. Materials: FÖ, YCÖ, KE. Data collection and/or processing: FFÖ, YCÖ, KE. Analysis and/or Interpretation: FÖ, YCÖ, KE. Literature Search: FÖ, YCÖ, KE. Writing Manuscript: FÖ, YCÖ, KE. Critical Review: FÖ.

Financial disclosure: The authors declared that this study received no financial support.

\section{REFERENCES}

1. Perry M, Lewis H, Thomas DR et al. Need for improved public health protection of young people wanting body piercing: evidence from a look-back exercise at a piercing and tattooing premises with poor hygiene practices. Epidemiol Infect 2018;30:1-7.

2. MacPherson P, Valentine K, Chadderton V et al. An outbreak of pseudomonas aeruginosa infection linked to a black friday piercing event. PLOS Curr 2017;9:ecurrents.outbreaks.51af24797f6f856a9861b5ddabc7db58.
3. López-Jornet P, Navarro-Guardiola C, Camacho-Alonso $\mathrm{F}$ et al. Oral and facial piercings: a case series and review of the literature. Int J Dermatol 2006;45:805-9.

4. Kapferer I, Beier US, Persson RG. Tongue piercing: the effect of material on microbiological findings. Journal of Adolescent Health 2011;49:76-83.

5. Scully C, Chen M. Tongue piercing (oral body art). Br J Oral Maxillofac Surg 1994;32:37-8.

6. Dayakar MM, Dayakar A, Akbar SM. Elective tongue piercing: fad with fallout. J Cutan Aesthet Surg 2015;8:71-2.

7. Ziebolz D, Hildebrand A, Proff P et al. Long-term effects of tongue piercing a case control study. Clin Oral Investig 2012;16:231-7.

8. Ram D, Peretz B. Tongue piercing and insertion of metal studs: three cases of dental and oral consequences. Journal of Dentistry for Children 2000;67:326-9.

9. Shacham R, Zaguri A, Librus HZ et al. Tongue piercing and its adverse effects. Oral Surg Oral Med Oral Pathol Oral Radiol Endod 2003;95:274-6.

10. Ziebolz D, Stuehmer C, Nüss K et al. Complications of tongue piercing: a review of the literature and three case reports. J Contemp Dent Pract 2009;10:65-71.

11. Bryan S, Lim J, Mackenzie N. Piercings: grossly swollen tongue. Br Dent J 2014;216:210-1.

12. Farah CS, Harmon DM. Tongue piercing: case report and review of current practice. Aust Dent J 1998;43:387-9.

13. Shinohara EH, Horikawa FK, Martinson Ruiz M et al. Tongue piercing: case report of a local complication. J Contemp Dent Pract 2007;8:83-9.

14. Escudero-Castaño N, Perea-García MA, Campo-Trapero J et al. Oral and perioral piercing complications. Open Dent J 2008;2:133-6.

15. Clapham E, Crooke J. The patient with a pierced tongue. Perioper Pract 2011;21:156-7. 